\title{
Celastrol inhibits production of nitric oxide and proinflammatory cytokines through MAPK signal transduction and NF- $k B$ in LPS-stimulated BV-2 microglial cells
}

\author{
Hyo Won Jung ${ }^{1}$, Yoo Sun Chung ${ }^{2}$, Yoon Seong Kim ${ }^{3}$, \\ and Yong-Ki Park ${ }^{1,4}$ \\ ${ }^{1}$ Department of Herbology \\ College of Oriental Medicine \\ Dongguk University \\ Gyeongju 780-714, Korea \\ ${ }^{2}$ Yong-In Internal Medicine Clinic \\ Gyeongju 780-956, Korea \\ ${ }^{3}$ Department of Neurology and Neuroscience \\ Weill Medical College of Cornell University \\ New York, NY 10021, USA \\ ${ }^{4}$ Corresponding author: Tel, 82-54-770-2661; \\ Fax, 82-54-770-2661; E-mail, yongki@ dongguk.ac.kr
}

Accepted 27 September 2007

Abbreviations: AD, Alzheimer's disease; PD, Parkinson's disease

\begin{abstract}
Excessive production of nitric oxide (NO) and proinflammatory cytokines from activated microglia play an important role in human neurodegenerative disorders. Here, we investigated whether celastrol, which has been used as a potent anti-inflammatory and anti-oxidative agent in Chinese medicine, attenuates excessive production of $\mathrm{NO}$ and proinflammatory cytokines such as TNF- $\alpha$ and IL-1 $\beta$ in LPS-stimulated BV-2 cells, a mouse microglial cell line. We report here that the LPS-elicited excessive production of NO, TNF- $\alpha$, and IL-1 $\beta$ in BV-2 cells was largely inhibited in the presence of celastrol, and the attenuation of inducible iNOS and these cytokines resulted from the reduced expression of mRNAs of iNOS and these cytokines, respectively. The molecular mechanisms that underlie celastrol-mediated attenuation were the inhibition of LPS-induced phosphorylation of MAPK/ERK1/2 and the DNA binding activity of NF- $\mathrm{B}$ B in BV-2 cells. The results indicate that celastrol effectively attenuated $\mathrm{NO}$ and proinflammatory cytokine production via the inhibition of ERK1/2 phosphorylation and NF-KB activation in LPS-activated microglia. Thus, celastrol may be an effective therapeutic candidate for use in the treatment of neurodegenerative human brain
\end{abstract}

disorders.

Keywords: anti-inflammatory agents; cytokines; extracellular signal-regulated MAP kinases; medicine, Chinese traditional; microglia; nitric oxide synthase type II; triterpene

\section{Introduction}

Microglia, the resident macrophages of the CNS, serve a role in immune surveillance and host defense (Baroon, 1995). When neuronal cells die, microglia are rapidly activated and produce reactive oxygen species (ROS), NO, and a variety of proinflammatory cytokines such as TNF- $\alpha, \mathrm{IL}-1 \beta$, and IL-6 (Boje and Arora, 1992; Chao et al., 1992; Liu and Hong, 2003; Kim and Joh, 2006). Studies using cell cultures and animal models such as Parkinson's disease (PD) and Alzheimer's disease (AD) have demonstrated that excessive quantities of individual toxic inflammatory mediators produced by activated microglia can contribute to the degeneration of neurons (Chao et al., 1992; McGuire et al., 2001). Thus, controlling microglial activation may have a therapeutic benefit in the treatment of many neurodegenerative diseases.

Celastrol is a pentacyclic-triterpene extracted from Tripterygium wilfordii Hook, a perennial creeping plant that is indigenous to a large area in southern China, is known as the "Thunder of God Vine", and belongs to family Celastraceae (Allison et al., 2001). Extracts containing celastrol have been given to Chinese patients for many years without any published reports of carcinogenicity or other limiting side effects (Li et al., 1997; Liu et al., 2003). Celastrol is reported to have anti-inflammatory properties such as inhibitory activity on the release of NO, TNF- $\alpha$, and IL-1 $\beta$ in LPS-stimulated human monocytes (Pinna et al., 2004) and mouse peritoneal macrophages (Xu et al., 1991; Suh et al., 1998; Lee et al., 2006). However, little is known of the inhibitory effects of celastrol in microglial activation, and several studies have mainly focused on its therapeutic effects in neurodegenerative diseases, including $A D$ and $P D$ (Allison et al., 2001; Cleren et al., 2005). Thus, celastrol seems to be a useful drug for the treat- 
ment of neurodegenerative diseases accompanied by inflammation, and an interesting candidate as a modulator of the inflammatory and immune response (Sethi et al., 2007).

Therefore, in the present study, we investigate the pharmacological effect of celastrol on LPSinduced inflammation in BV-2 microglial cells. We also examined the working mechanism of microglial activation by regulation of mRNA transcription, MAPK phosphorylation, and NF- $\mathrm{B}$ activation.

\section{Materials and Methods}

\section{Cell culture}

The BV-2 cells, a mouse microglia line, were maintained in DMEM supplemented with $5 \%$ heatinactivated FBS (Hyclone, Logan, UT) and 1\% streptomycin/penicillin (Gibco, Grand Island, NY) under a humidified atmosphere of $5 \% \quad \mathrm{CO}_{2} / 95 \%$ air. Prior to each experiment, cells were plated in 24-well plates at a density of $1 \times 10^{5}$ cells for culture supernatant tests or in 6-well plates at a density of $2 \times 10^{5}$ cells for protein extraction and RNA extraction. The next day, the cells were pre-treated with celastrol (Microsource, Gaylordsville, CT) for $30 \mathrm{~min}$ as indicated in the figures, followed by stimulation with LPS (serotype O111: B4, $10 \mathrm{ng} / \mathrm{ml}$; Sigma, St Louis, MO) for the indicated amount of time.

\section{Lactate dehydrogenase (LDH) release assay}

Cytotoxicity was determined by measuring the release of LDH. BV-2 cells were treated with different concentrations ( $1 \mathrm{nM}, 100 \mathrm{nM}$, and $10 \mu \mathrm{M})$ of celastrol in the absence or presence of LPS (10 $\mathrm{ng} / \mathrm{ml}$ ) for $3,6,12$, and $24 \mathrm{~h}$, and the culture medium was used to assay LDH activity. The reaction was initiated by mixing $0.1 \mathrm{ml}$ of cell-free supernatant with potassium phosphate buffer containing $\mathrm{NADH}$ and sodium pyruvate in a final volume of $0.2 \mathrm{ml}$ in 96 -well plates. The absorbance values were read at $490 / 630 \mathrm{~nm}$ on an automated SpectraMAX 340 microtiter plate reader. Data were expressed as the mean LPS-treated cells (100\%) vs. control or celatrol-treated cells.

\section{NO release assay}

BV-2 cells were pre-treated with various concentrations of celastrol $(1,10$, and $100 \mathrm{nM})$ for $30 \mathrm{~min}$ prior to stimulation with LPS $(10 \mathrm{ng} / \mathrm{ml})$ for $24 \mathrm{~h}$. The culture media were removed and assayed for nitrite production, a stable metabolite byproduct of NO generation, using the Greiss reagents ( $1 \%$ sulfanilamide / 0.1\% N-(1-naphthyl)-ethylenediamine dihydrocholoride / $2.5 \%$ phosphoric acid). In brief, $100 \mu \mathrm{l}$ medium or sodium nitrite standards were transferred to a 96-well plate, followed by the addition of $100 \mu \mathrm{l}$ of Greiss reagent. The absorbance values were read at $540 \mathrm{~nm}$ on an automated SpectraMAX 340 microtiter plate reader. NO concentration was calculated with reference to the standard curve of sodium nitrite generated by known concentrations.

\section{ELISA}

The levels of two cytokines, TNF- $\alpha$ and IL-1 $\beta$, were assessed by ELISA using monoclonal antibodies and the procedure recommended by the supplier (eBiosciences, San Diego, CA). Cells were pre-treated with various concentrations of celastrol (1, 10 and $100 \mathrm{nM}$ ) for $30 \mathrm{~min}$ prior to stimulation with LPS $(10 \mathrm{ng} / \mathrm{ml})$ for $6 \mathrm{~h}$ (for TNF- $\alpha$ ) and $24 \mathrm{~h}$ (for IL-1 $\beta$ ). Supernatants were collected and used for the analysis of TNF- $\alpha$ and IL-1 $\beta$ by ELISA. The concentration of each cytokine was calculated according to the standard curve of the ELISA kits.

\section{RNA extraction and RT-PCR}

BV-2 cells were pre-treated with $100 \mathrm{nM}$ of celastrol for $30 \mathrm{~min}$ prior to stimulation with LPS $(10 \mathrm{ng} / \mathrm{ml})$ for $6 \mathrm{~h}$. Total cellular RNA was isolated from cells in $0.5 \mathrm{ml}$ of Trizol reagent (Invitrogen, Carlsbad, CA). After treatment with DNase I (Promega, Madison, WI) for $30 \mathrm{~min}$ at $37^{\circ} \mathrm{C}, 1 \mu \mathrm{g}$ of total RNA was reverse transcribed for $1 \mathrm{~h}$ at $42^{\circ} \mathrm{C}$ in a reaction mixture containing RNA, $5 \mathrm{U}$ RNase inhibitor (Amersham, Piscataway, NJ), 0.5 $\mathrm{mM}$ deoxynucleotide triphosphate (dNTP), $0.5 \mu \mathrm{M}$ oligo-dT primer, $1 \times$ reverse transcriptase buffer, and $5 \mathrm{U}$ of Superscript Reverse Transcriptase (Promega, Madison, WI) in a total volume of $20 \mu \mathrm{l}$. PCR was performed using the above prepared cDNA as a template with the following cycle parameters: $94^{\circ} \mathrm{C}, 2 \mathrm{~min}, 30-35$ cycles; $94^{\circ} \mathrm{C}, 30 \mathrm{~s}$; $57-62^{\circ} \mathrm{C}, 30 \mathrm{~s} ; 72^{\circ} \mathrm{C}, 1 \mathrm{~min} ; 92^{\circ} \mathrm{C}, 10 \mathrm{~min}$. PCR reaction products were then run on $1 \%$ agarose gels at $100 \mathrm{~V}$ and visualized with ethidium bromide (EtBr; $0.5 \mu \mathrm{g} / \mathrm{ml}$ ). Verification of specific genes was established by assessing their predicted sizes under UV light. The primer sequences are as follows: sense; 5'-GGCTGTCAGAGCCTCGTGGCTTTGG-3', anti-sense; 5'-CCCTTCCGAAGTTTCTGGCAGCAGC-3' for iNOS; sense; 5'-GGCAGGTCTACTTTGGAGTCATTGC-3', anti-sense; 5'ACATTCGAGGCTCCAGTGAATTCGG-3' for TNF$\alpha$; sense; 5'-ATGGCAACTGTTCCTGAACTCAAC- 
T-3', anti-sense; 5'-CAGGACAGGTATAGATTCTTTCCTTT-3' for IL-1 $\beta$; and 5'-CTCGTGGAGTCTACTGGTGT-3', 5'-GTCATCATACTTGGCAGGTT-3' for $\beta$-actin as a control for PCR.

\section{Western blot analysis}

BV-2 cells were pre-treated with $100 \mathrm{nM}$ of celastrol or $30 \mu \mathrm{M}$ of ERK inhibitor (PD98059; Calbiochem, San Diego, CA) for 30 min prior to stimulation with LPS (10 ng/ml) for $24 \mathrm{~h}$ (for iNOS) and 15 min (for ERK1/2). Whole cell extracts were prepared by lysing cells for $30 \mathrm{~min}$ on ice in lysis buffer $(10 \mathrm{mM}$ Tris- $\mathrm{HCl}, \mathrm{pH} 7.9,10 \mathrm{mM} \mathrm{NaCl}, 3$ $\mathrm{mM} \mathrm{MgCl} 2,1 \% \mathrm{NP}-40$ ), followed by centrifugation at $12,000 \mathrm{rpm}$ for $10 \mathrm{~min}$. The protein concentration was determined with Lowry protein assay solution (Bio-Rad, Hercules, CA). Twenty micrograms of protein were separated by $10 \%$ SDSPAGE and then transferred to nitrocellulose membranes (Hybond ECL, Amersham, Piscataway, NJ). The membranes were blocked with $5 \%$ skim milk (Difco, Becton, Dickinson and Company, Sparks, $\mathrm{MD}$ ) in $10 \mathrm{mM}$ Tris- $\mathrm{HCl}$ containing $150 \mathrm{mM} \mathrm{NaCl}$ and $0.5 \%$ Tween-20 (TBST), and were then incubated overnight with primary antibodies at $4^{\circ} \mathrm{C}$, followed by incubation with HRP-conjugated secondary antibodies (Sigma). The blots were developed using an enhanced chemiluminescence detection kit (Amersham). The antibodies used in this study were anti-iNOS $(1: 1,000$, SantaCruz Biotechnology, Santa Cruz, CA), anti-phosphoERK1/2 (1:1,000, Cell Signaling, Beverly, MA), and anti- $\beta$-actin (1:2,000, Sigma).

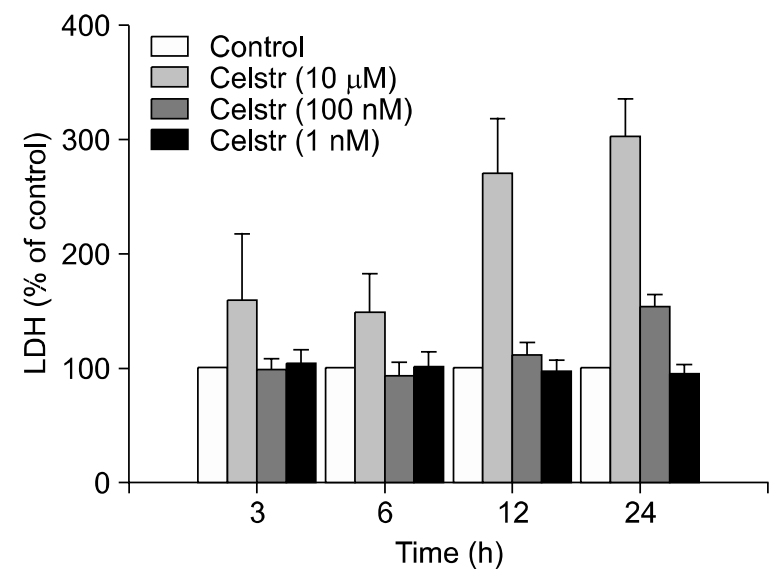

Figure 1. Effect of celastrol on the cytotoxicity in BV-2 cells. Cells were treated with various concentrations of celastrol and incubated for $3,6,12$, and $24 \mathrm{~h}$. The cytotoxicity of celastrol was measured by LDH release assay. Data represent the mean \pm SEM of three independent experiments.

\section{Nuclear extraction and electrophoretic mobility shift assay (EMSA)}

Nuclear extracts from BV-2 cells were prepared as follows: cells were treated with $1 \mathrm{ml}$ of lysis buffer on ice for $30 \mathrm{~min}$. After centrifugation at $1,500 \times \mathrm{g}$ for $10 \mathrm{~min}$, the pellet was resuspended in $50 \mu \mathrm{l}$ of extraction buffer (20 mM HEPES, pH 7.9, 20\% glycerol, $1.5 \mathrm{mM} \mathrm{MgCl} 2,0.2 \mathrm{mM}$ EDTA, $1 \mathrm{mM}$ DTT, $1 \mathrm{mM}$ PMSF) and incubated on ice for $30 \mathrm{~min}$. After centrifugation at $1,500 \times g$ for $5 \mathrm{~min}$, the supernatant was harvested as the nuclear protein extract and stored at $-70^{\circ} \mathrm{C}$ until use. The protein concentration was determined with Lowry protein assay solution (Bio-Rad, Hercules, CA). Ten micrograms of the nuclear proteins were incubated with ${ }^{32} \mathrm{P}$-labeled $\mathrm{NF}-\kappa \mathrm{B}$ probe on ice for $30 \mathrm{~min}$ and resolved on $5 \%$ acrylamide gel.

\section{Statistical analysis}

Experiments were independently performed a minimum of three times, and the data are presented as

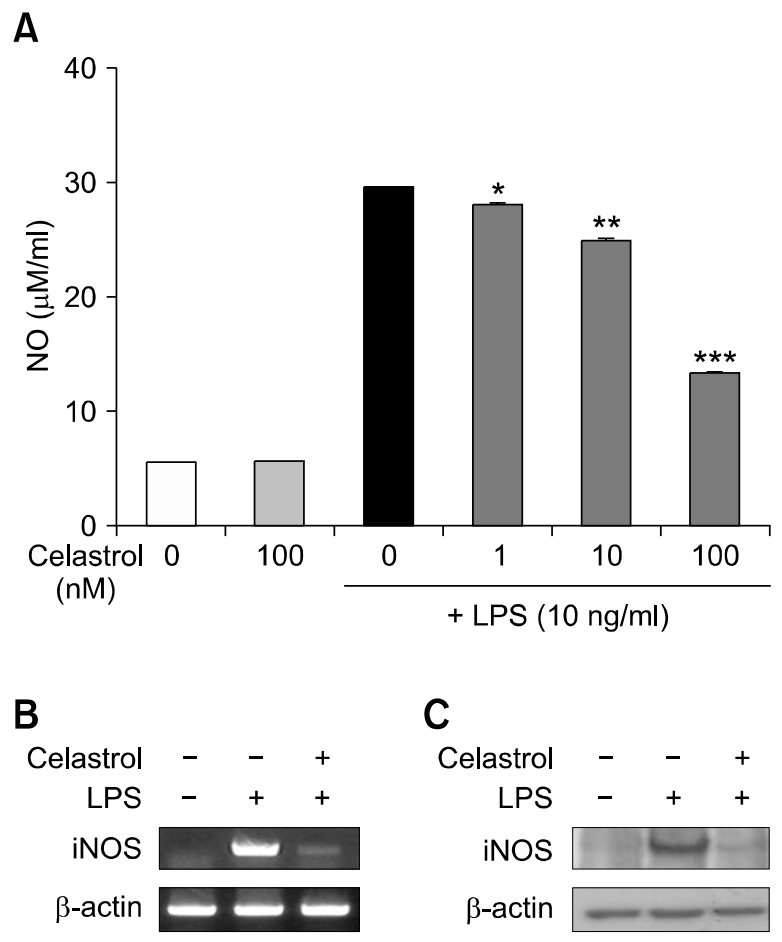

Figure 2. Effect of celastrol on LPS-induced production of NO in BV-2 cells. (A) Cells were treated with celastrol $(1,10$, and $100 \mathrm{nM})$ in the absence or presence of LPS $(10 \mathrm{ng} / \mathrm{ml})$ for $24 \mathrm{~h}$. The NO concentration was determined in culture medium using Griess reagent. Data represent the mean \pm SEM of three independent experiments. ${ }^{*} P<0.05$, ${ }^{* *} P<$ 0.01 , and ${ }^{* * *} P<0.001$ vs. LPS alone. (B and $C$ ) Cells were treated with celastrol (100 nM) in the absence or presence of LPS for $6 \mathrm{~h}$ for RT-PCR and $24 \mathrm{~h}$ for Western blot. The mRNA expression and protein levels of iNOS were evaluated by RT-PCR and Western blot. 
the mean \pm SEM (standard error of the mean). Data were analyzed using Student's $t$-test and one way ANOVA. Statistical significance was established at $P<0.05$.

\section{Results}

\section{Inhibition of NO production by celastrol}

To investigate the effects of celastrol on NO production in LPS-stimulated BV-2 cells, cells were treated with LPS alone or with various concentrations of celastrol for $24 \mathrm{~h}$. NO production was determined by measuring the levels of a stable NO metabolite, nitrite, in the culture medium by Griess reaction. At the concentrations used in this study, none of the celastrol treatments caused toxicity to cells, as confirmed by the LDH assay (Figure 1). Celastrol decreased the LPS-induced production of $\mathrm{NO}$ in BV-2 cells in a dose-dependent manner (Figure 2A). Next, to elucidate the mechanism responsible for the inhibitory effect of celastrol on NO production, we determined the iNOS mRNA and protein levels by RT-PCR and Western blot analysis. At a concentration of $100 \mathrm{nM}$, celastrol effectively inhibited iNOS mRNA expression (Figure 2B) and its LPS stimulation-induced protein levels (Figure 2C) in BV-2 cells to a near basal level. These data suggest that celastrol acts principally by regulating the accumulation of $\mathrm{NO}$ at the post-transcriptional level, and that it could be a suppressor of microglial activation.

\section{Inhibition of proinflammatory cytokine production by celastrol}

To investigate the anti-inflammatory effect of celastrol, we determined the production of proinflammatory cytokines, including TNF- $\alpha$ and IL-1 $\beta$, by stimulating BV-2 cells with LPS in the presence of celastrol. As shown in Figure 3, the stimulation of microglia by LPS increased the production of TNF- $\alpha$ and IL-1 $\beta$, and celastrol treatment inhibited their production in BV-2 cells in a dose-dependent manner. To elucidate the mechanism responsible for the inhibitory effect of celastrol on TNF- $\alpha$ and
A

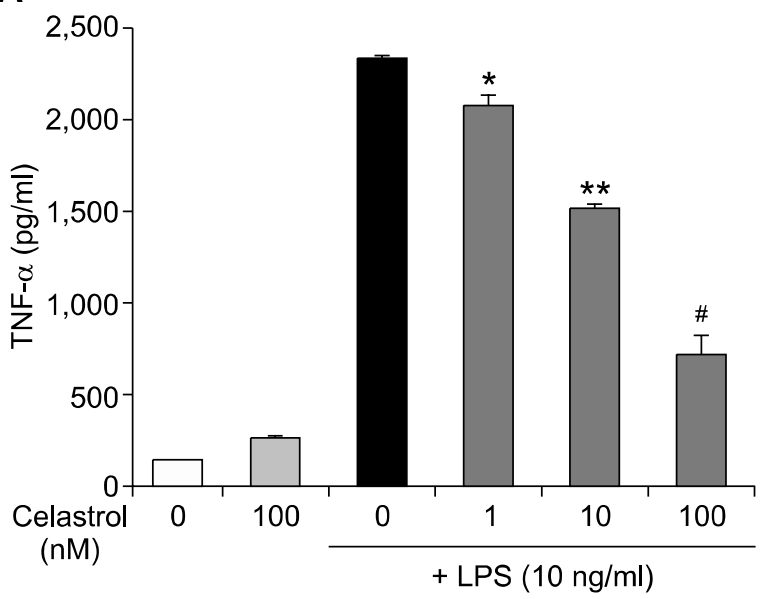

C

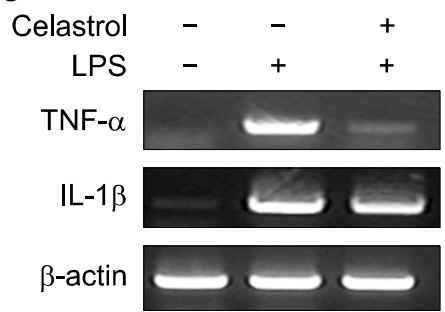

B

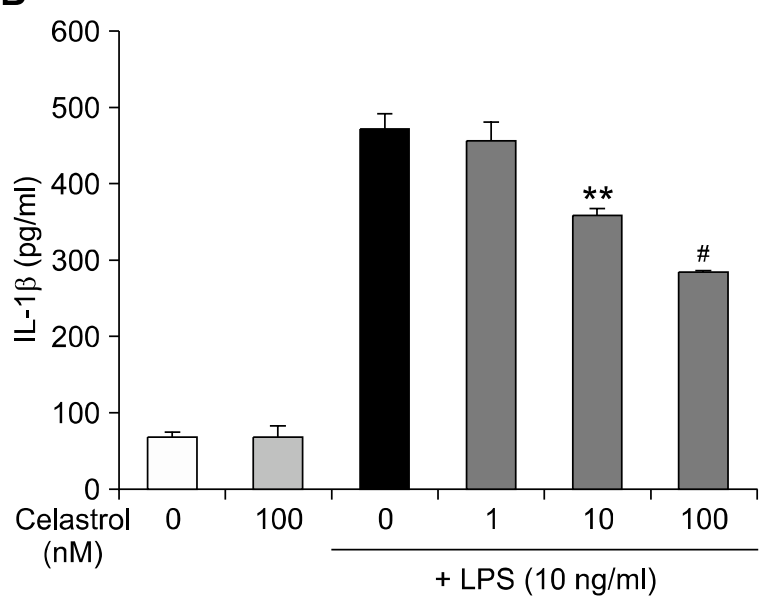

Figure 3. Effect of celastrol on LPS-induced production of proinflammatory cytokine in BV-2 cells. (A) Cells were treated with celastrol (1, 10, and 100 nM) in the absence or presence of LPS $(10 \mathrm{ng} / \mathrm{ml})$ for $6 \mathrm{~h}$ for RT-PCR and $24 \mathrm{~h}$ for ELISA. Each cytokine concentration was measured in culture medium using ELISA. Data represent the mean \pm SEM of three independent experiments. ${ }^{*} P<0.05$, ${ }^{* *} P<0.01$, and ${ }^{\sharp} P<0.001$ vs. LPS alone. (B) Cells were treated with celastrol $(100 \mathrm{nM})$ in the absence or presence of LPS for $6 \mathrm{~h}$. The mRNA expression of each cytokine was evaluated by RT-PCR. 
A

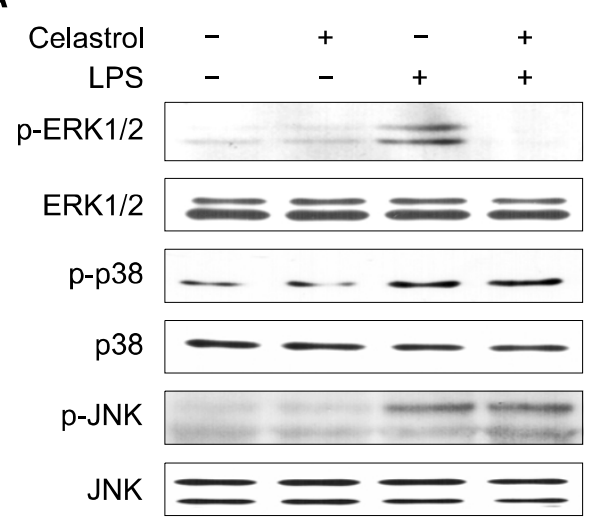

B

$\begin{array}{rlllll}\text { Celastrol } & - & + & - & + & - \\ \text { LPS } & - & - & + & + & + \\ \text { PD98059 } & - & - & - & - & + \\ \text { p-ERK1/2 } \\ \text { ERK1/2 }\end{array}$

Figure 4. Effect of celastrol on LPS-induced phosphorylation of MAPK molecules in BV-2 cells. (A) Cells were treated with celastrol $(100 \mathrm{nM})$ in the absence or presence of LPS (10 ng/ml) for $15 \mathrm{~min}$. (B) Cells were treated with celastrol (100 nM) or an ERK inhibitor, PD98059 $(30 \mu \mathrm{M})$, in the absence or presence of LPS for $15 \mathrm{~min}$. Total cell extracts were subjected to immunoblot analysis using antibodies against phosphor- or total forms of three MAPKs.

IL-1 $\beta$ production, we next determined the cytokine mRNA expression levels by RT-PCR analysis. Celastrol markedly decreased the mRNA expression levels of both TNF- $\alpha$ and IL- $1 \beta$ in BV-2 cells (Figure 2A). These data suggest that celastrol might act as a modulator of the accumulation of inflammatory cytokine production at a post-transcriptional level.

\section{Inhibition of ERK1/2 MAPK phosphorylation and NF-KB activation by celastrol}

We then assessed whether the repressive effect of celastrol on gene expression occurred via alteration of MAPK activity. As shown in Figure 4, celastrol did not inhibit LPS-induced phosphorylation levels of p38 and pJNK MAPKs in BV-2 cells (Figure 4A). While LPS-induced phosphorylation of ERK1/2 MAPK was greatly inhibited by celastrol and ERK inhibitor (PD98059) in cells, non-phosphorylated ERK remained the same (Figure 4B). These findings indicate that celastrol is effective in the inhibition of ERK phosphorylation in LPS-sti-

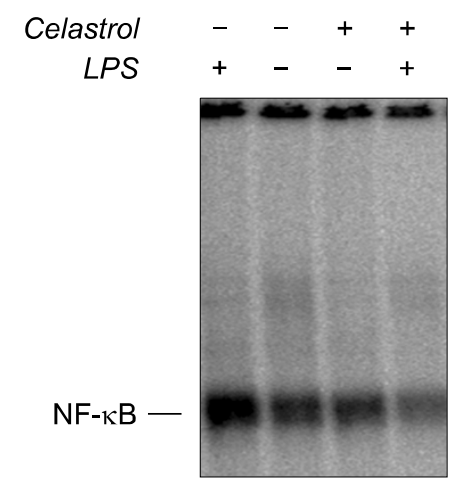

Figure 5. Effects of celastrol on LPS-stimulated NF-KB DNA binding activity in BV-2 cells. Cells were treated with celastrol $(100 \mathrm{nM})$ in the presence or absence of LPS $(10 \mathrm{ng} / \mathrm{ml})$ for $1 \mathrm{~h}$. Total nuclear extracts were isolated and used in an electrophoretic mobility shift assay with ${ }^{32} \mathrm{P}$-labeled NF-KB oligonucleotide as a probe. The arrow indicates the p65 $\mathrm{NF}-\mathrm{KB}$ binding complex.

mulated microglial cells. We next examined the

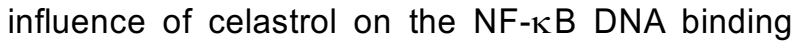
activity using EMSA. As shown in Figure 5, celastrol suppressed the LPS-induced DNA binding activity of NF- $\mathrm{KB}$ at a concentration of $100 \mathrm{nM}$ in BV-2 cells, which indicated the involvement of the NF-кB pathway.

\section{Discussion}

The various therapies to treat neurodegenerative diseases have specifically included therapeutic modalities aimed to control the pathophysiological mechanisms that lead to the systemic inflammatory response. Microglia are potential sources and targets of relevant neuroprotective factors as well as neurotoxins because their uncontrolled activation may contribute to neurotoxicity in human brain disorders (McGeer et al., 1993; Barron, 1995; Giulian et al., 1996). The activated microgliaderived proinflammatory factors, which include inflammatory cytokines and NMDA receptor antagonists as well as oxygen free radicals and nitric oxide (NO), have long been believed to be involved with neuroinflammation in neurodegenerative diseases, including $P D$ and $A D$ (Boje and Arora, 1992; Chao et al., 1992). Thus, intervention of microglial activation has become a therapeutic target for the treatment of many neurodegenerative conditions (Liu and Hong, 2003; Kim and Joh, 2006). In this study, we studied celastrol, a natural component of Tripterygium wilfordii Hook, in LPSactivated BV-2 microglial cells in terms of the production of $\mathrm{NO}$ and proinflammatory cytokines, and evaluated the therapeutic potential for treatment of human neurodegenerative disorders. 
NO is known to be involved in the processes of CNS inflammation. iNOS is the key enzyme for NO production, and is quantitatively induced in activated glial cells after exposure to stimulators such as LPS and viral infections (McGeer et al., 1993; Chew et al., 2006). Therefore, agents with the ability to inhibit iNOS expression are potentially beneficial in the treatment of conditions associated with an overproduction of NO, including septic shock, inflammation, and neurodegenerative diseases (Hobbs et al., 1999). In the present study, celastrol decreased the NO production induced in LPS-activated BV-2 cells in a dose-dependent manner (Figure 2A), and largely reduced the mRNA expression and protein levels of iNOS in BV-2 cells (Figure 2B and C), which indicated that the inhibition of NO production by celastrol is a result of the inhibition of iNOS gene expression. Indeed, the change of redox status by many antioxidant chemicals in macrophage cells has been reported to directly or indirectly regulate some initiation factors and RNA binding proteins that regulate the translation or stability of iNOS mRNA (Fukuda et al., 1999; Chen et al., 2004).

TNF- $\alpha$ and IL-1 are the two main proinflammatory cytokines produced by activated microglia during inflammation caused by the disruption of the brain-blood barrier (BBB) (Chap et al., 1995; Chew et al., 2006). Celastrol has previously been known to inhibit in vitro TNF- $\alpha$ and IL-1 $\beta$ secretion in LPS-activated human peripheral blood monocytes and THP-1 cells (Pinna et al., 2004), as well as in mouse peritoneal macrophage cells ( $\mathrm{Xu}$ et al., 1991; Suh et al., 1998; Lee et al., 2006). We found that celastrol inhibits LPS-induced production of proinflammatory cytokines, TNF- $\alpha$ and IL-1 $\beta$ (Figure $3 \mathrm{~A}$ ), and the expression of their mRNA (Figure $3 \mathrm{~B}$ ) in BV-2 cells. This result indicates that celastrol is able to modulate the activities of TNF- $\alpha$ and IL-1 $\beta$ at the transcriptional or mRNA stabilization levels in activated microglia.

LPS stimulation induces its inflammatory effects through the activation of both MAPKs signaling and the classical NF-KB pathway (Sanghera et al., 1996). Although the exact intracellular signal pathways of microglial activation by LPS have not been clearly defined, LPS has been reported to induce iNOS and TNF expression in microglial cells through signal pathways, including ERK1/2, p38 MAPK, and NF-кB (Bhat et al., 1998; Shen et al., 2005). Thus, inhibition of these signaling pathways may explain the potent activity of celastrol as a suppressor of inflammatory mediators. Recently, various natural compounds, including baicalein, berberine, curcumin, luteolin, and resveratrol, have been reported to inhibit the overproduction of inflammatory mediators such as NO, COX-2, and TNF- $\alpha$ in LPS-stimulated BV-2 cells (Suk et al., 2003; Kang et al., 2004; Kim et al., 2006) and primary microglia (Chen et al., 2004). Interestingly, these compounds have already been shown to be

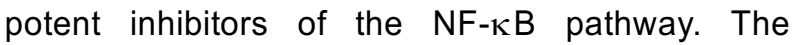
present study demonstrated that celastrol largely inhibited ERK1/2 MAPK phosphorylation (Figure 4) and NF- $\kappa B$ DNA binding activity (Figure 5) in LPS-induced microglial activation. This finding suggests that the transcriptional downregulation of the inflammatory mediators by celastrol results from the inhibition of the ERK MAPK and NF-KB signal pathways.

The BBB maintains the homeostasis of the brain microenvironment, which is crucial for neuronal activity and function (Cucullo et al., 2004). Thus, whether various components, including celastrol, might pass through the BBB is important in terms of their potential use in the treatment of many brain disorders. The neuroprotective effects of celastrol in conditions accompanied by inflammation, such as $A D$ and $P D$ in rats and mice, have been described previously (Allison et al., 2001; Cleren et al., 2005), while there is no report or evidence on whether it might pass through the BBB and upregulate dopamine synthesis or inhibit the metabolism of either dopamine or MPP ${ }^{+}$. In this study, we did not investigate whether celastrol might pass through the BBB or whether it can exist at detectable tissue concentrations in the brain. In further study, we will test the efficacy of a putative neuroprotective drug, celastrol, using an in vivo model of PD.

In conclusion, we demonstrated that celastrol exhibits anti-inflammatory activity through inhibition of inflammatory mediators such as NO, TNF- $\alpha$, and IL-1 $\beta$ resulting from the downregulation of their gene transcription levels in LPS-activated BV-2 cells. The anti-inflammatory properties of celastrol were mediated by the inhibition of ERK MAPK phosphorylation and NF- $\kappa B$ activation in cells. These data suggest that celastrol is a potent suppressor of LPS-induced inflammatory status in activated microglia, and a potential therapeutic agent for use in the treatment of various neurodegenerative diseases.

\section{Acknowledgement}

This work was supported by a grant from Dongguk University, Republic of Korea. 


\section{References}

Allison AC, Cacabelos R, Lombardi VR, Alvarez XA, Vigo C. Celastrol, a potent antioxidant and anti-inflammatory drug, as a possible treatment for Alzheimer's disease. Prog Neuropsychopharmacol Biol Psychiatry 2001;25:1341-57

Barron KD. The microglial cell. A historical review. J Neurol Sci 1995;134:57-68

Bhat NR, Zhang P, Lee JC, Hogan E. Extracellular signalregulated kinase and p38 subgroups of mitogen-activated protein kinases regulate inducible nitric oxide synthase and tumor necrosis factor- $\alpha$ gene expression in endotoxin-stimulated primary microglial cultures. J Neuroscience 1998; 18:1633-41

Boje KM, Arora PK. Microglia-produced nitric oxide and reactive nitrogen oxides mediate neuronal cell death. Brain Research 1992;587:250-6

Chao CC, Hu S, Molitor TW, Shaskan EG, Peterson PK. Activated microglia mediate neuronal cell injury via a nitric oxide mechanism. J Immunology 1992;149:2736-41

Chap CC, Hu S, Ehrlich L, Peterson PK. Interleukin-1 and tumor necrosis factor- $\alpha$ synergistically mediate neurotoxicity: involvement of nitric oxide and of $\mathrm{N}$-methyl-Daspartate receptors. Brain Behav Immunology 1995;9: 355-65

Chen CJ, Raung SL, Liao SL, Chen SY. Inhibition of inducible nitric oxide synthase expression by baicalein in endotoxin/ cytokine-stimulated microglia. Biochem Pharmacol 2004; 67:957-65

Chew LJ, Takanohashi A, Bell M. Microglia and inflammation: Impact on developmental brain injuries. Mental Retardation and Developmental Disabilities 2006;12:105-12

Cleren C, Calingasan NY, Chen J, Beal MF. Celastrol protects against MPTP- and 3-nitropropionic acid-induced neurotoxicity. J Neurochem 2005;94:995-1004

Cucullo L, Hallene K, Dini G, Dal Toso R, Janigro D. Glycerophosphoinositol and dexamethasone improve transendothelial electrical resistance in an in vitro study of the bloodbrain barrier. Brain Res 2004;997:147-51

Fukuda K, Hibiya Y, Mutoh M, Koshiji M, Akao S, Fujiwara H. Inhibition by berberine of cyclooxygenase-2 transcriptional activity in human colon cancer cells. J Ethnopharmacology 1999;66:227-33

Giulian D, Corpuz M, Richmond B. Activated microglia are the principal microglial source of thromboxane in the CNS Neurochem Int 1996;29:65-76

Hobbs AJ, Higgs A, Moncada S. Inhibition of nitric oxide synthase as a potential therapeutic target. Annual Review of Pharmacology and Toxicology 1999;39:191-220

Kang G, Kong PJ, Yuh YJ, Lim SV, Chun W, Kim SS. Curcumin suppresses lipopolysaccharide-induced cyclooxygenase-2 expression by inhibiting activator protein 1 and nuclear factor kappab bindings in BV-2 microglial cells. J Pharmacol Science 2004;94:325-28

Kim EK, Kwon KB, Han MJ, Song MY, Lee JH, Lv N, Ka SO, Yeom SR, Kwon YD, Ryu DG, Kim KS, Park JW, Park R, Park
$\mathrm{BH}$. Coptidis rhizoma extract protects against cytokineinduced death of pancreatic beta-cells through suppression of NF-kappaB activation. Exp Mol Med 2007;39:149-59

Kim JS, Lee HJ, Lee MH, Kim J, Jin C, Ryu JH. Luteolin inhibits LPS-stimulated inducible nitric oxide synthase expression in BV-2 microglial cells. Planta Med 2006;72:65-8

Kim YS, Joh TH. Microglia, major player in the brain inflammation: their roles in the pathogenesis of Parkinson's disease. Exp Mol Med 2006;38:333-47

Lee JH, Koo TH, Yoon H, Jung HS, Jin HZ, Lee K, Hong YS, Lee JJ. Inhibition of NF-kappa B activation through targeting I kappa B kinase by celastrol, a quinone methide triterpenoid. Biochem Pharmacol 2006;72:1311-21

Li H, Jia YF, Pan Y, Pan DJ, Li D, Zhang LX. Effect of tripterine on collagen-induced arthritis in rats. Zhongguo Yao Li Xue Bao 1997;18:270-73

Liu B, Hong JS. Role of microglia in inflammation-mediated neurodegenerative diseases: mechanisms and strategies for therapeutic intervention. J Pharmacology and Experimental Therapeutics 2003;304:1-7

McGeer FL, Kawamata T, Walker DG, Akiyama H, Tooyama I, McGeer EG. Microglia in degenerative neurological diease. Glia 1993;7:84-92

McGuire SO, Ling ZD, Lipton JW, Sortwell CE, Collier TJ, Carvey PM. Tumor necrosis factor alpha is toxic to embryonic mesencephalic dopamine neurons. Experimental Neurology 2001;169:219-30

Pinna GF, Fiorucci M, Reimund JM, Taquet N, Arondel Y, Muller CD. Celastrol inhibits pro-inflammatory cytokine secretion in Crohn's disease biopsies. Biochem Biophys Res Commun 2004;322:778-86

Sanghera JS, Weinstein SL, Aluwalia M, Girn J, Pelech SL. Activation of multiple protein-directed kinases by bacterial lipopolysaccharide in murine macrophages. J Immunology 1996;156:4457-65

Sethi G, Ahn KS, Pandey MK, Aggarwal BB. Celastrol, a novel triterpene, potentiates TNF-induced apoptosis and suppresses invasion of tumor cells by inhibiting NF-kappaB-regulated gene products and TAK1-mediated NF-kappaB activation. Blood 2007;109:2727-35

Shen S, Yu S, Binek J. Distinct signaling pathways for induction of type II NOS by IFN- $\gamma$ and LPS in BV-2 microglial cells. Neuroscience 2005;22:3352-58

Suh N, Honda T, Finlay HJ, Barchowsky A, Williams C, Benoit NE, Xie QW, Nathan C, Gribble GW, Sporn MB. Novel triterpenoids suppress inducible nitric oxide synthase (iNOS) and inducible cyclooxygenase (COX-2) in mouse macrophages. Cancer Research 1998;58:717-23

Suk KH, Lee HS, Kang SS, Cho GJ, Cho WS. Flavonoid baicalein attenuates activation-induced cell death of brain microglia. J Pharmacology and Experimental Therapeutics 2003;305:638-45

Xu WM, Zhang LX, Cheng ZH, Cai WZ, Miao HH, Pan DJ. Inhibitory effect of triterpene on activities of IL-1, IL-2 and release of PGE2. Yao Xue Xue Bao 1991;26:641-645 